\title{
Effect of Integrated Nutrient Management on Hybrid Napier Production under Irrigated Conditions
}

\author{
Om Singh $^{1^{*}}$, V.B. Chaturvedi ${ }^{2}$, M.R. Verma ${ }^{3}$ and H.C. Singh ${ }^{2}$ \\ ${ }^{1}$ Livestock Production Management Section, ICAR - Indian Veterinary Research Institute, \\ Izatnagar, Bareilly-243122 (U.P.), India \\ ${ }^{2}$ Division of Animal Nutrition, ICAR - Indian Veterinary Research Institute, Izatnagar, \\ Bareilly-243122 (U.P.), India \\ ${ }^{3}$ Division of LES \& IT, ICAR - Indian Veterinary Research Institute, Izatnagar, \\ Bareilly-243122 (U.P.), India \\ *Corresponding author
}

\section{A B S T R A C T}

A field experiment was conducted during 2013-14 and 2014-15 at Izatnagar, Uttar Pradesh, to study the effect of integrated nutrient management in napier hybrid grass production under irrigation. Experiment was conducted with application of $100 \%$ RDF

Keywords

INM, Napier hybrid, Yield, CP

Article Info

Accepted:

23 March 2018 Available Online:

10 April 2018 (Recommended dose of fertilizers), $75 \% \mathrm{RDF}$ along with 5t/ha Vermi-compost + biofertilizers, $75 \% \mathrm{RDF}$ along with 5t/ha FYM + bio-fertilizers and 75\% RDF alone. Four cuttings were taken at the interval of 90 days after planting during both the years. Plant height, green fodder yield, dry yield, crude protein yield, etc. were estimated. Application of $75 \% \mathrm{RDF}$ along with $5 \mathrm{t} / \mathrm{ha}$ Vermi-compost + bio-fertilizers gave significant higher plant growth and mean yield of fodder $(69.75 \mathrm{t} / \mathrm{ha} / \mathrm{cut})$ than $100 \% \mathrm{RDF}$ alone (65.35t/ha/cut) followed by $75 \% \mathrm{RDF}+5 \mathrm{t} / \mathrm{ha} \mathrm{FYM}+$ bio-fertilizers application $(67.73$ t/ha/cut). It has been observed that $25 \%$ of RDF can spared successfully without compromising the fodder production if Vermi-compost and or FYM added @ of 5 tones per hectare along with bio-fertilizers. Result also shows that $75 \%$ RDF alone significantly lowers the yield of green fodder $(58.48 \mathrm{t} / \mathrm{ha})$ and dry matter yield $(11.07 \mathrm{t} / \mathrm{ha})$. First cut produced significantly higher yield of fodder, DM, CP, CF over the $3^{\text {rd }}$ and $4^{\text {th }}$ cut. However, it was at par with second cut of Napier hybrid grass.

\section{Introduction}

Hybrid Napier is a popular fodder grass among farmers due to its high yielding potential and nutritive value with the advent of some high yielding cultivars such as ' $\mathrm{CO}-3$ ' and 'CO-4' which yields 300-400 t/ha/year fresh fodder. Hybrid Napier (bajra-Napier hybrid) is the F1 hybrid of bajra (Pennisetum glaucums (L.) R.Br.) and Napier grass (Pennisetum purpeureum Schum.). Anthony and Thomas (2014) reported that hybrid Napier cultivars such as 'CO-3' and 'CO-4' can be recommended for rain-fed conditions also as they can survived during summer drought periods. 'Co-3' and 'Co-4' are cultivars released from Tamilnadu Agricultural University. Optimum crop 
productivity can only be achieved by a combination of managemental strategies of effective and efficient nutrient management, large amount of nutrients is being exported from the soil through produce and stubble, however ex-situ or in-situ green manures, animal manure, cover crops, or different types of organic matters are used individually or in combination to replenish exported nutrients in organic systems. L. Shukla et al., 2009 reported that high concentration of bacteria around the roots (i.e. in the rhizosphere); presumably occurs because of the presence of high levels of nutrients (especially small molecules such as amino acids, sugars and organic acids) that are exuded from roots of most plants and can thus be used to support bacterial growth and metabolism also replenish the nutrients.

In the tropics, where soil fertility is generally low which decline the crop yields, even in conventional cropping systems due to excess soil mining, calls for the inclusion of organic matter to maintain soil fertility therefore, addition of organic matter becomes very important.

Significant efforts have been made to economise the use of fertilizers in field crops through application of bio-fertilizers and farm yard manure (FYM). Long-term fertilizer effects show that application of fertilizer alone has a deleterious effect on soil health and crop productivity. Integration of various sources of nitrogenous (organic and inorganic) fertilizers is more suitable because it reduces the application of chemical fertilizers and cost of cultivation, besides it is an environment friendly approach too (Sharma et al., 2007).

Napier hybrid is one of the important perennial forage crops of the country is mostly grown under irrigated conditions in the western Uttar Pradesh to supply green fodder for livestock production. Therefore, the present study was conducted to study the effect of replacing $25 \%$ RDF through vermicompost and /or FYM along with biofertilizers in Bareilly district of U.P.

\section{Materials and Methods}

A field experiment was conducted at ICARIVRI, Izatnagar, Uttar Pradesh, during 201314 and 2014-15 on sandy loam soil, having $\mathrm{pH}$ 7.5. The soil was low in organic carbon $(0.45 \%)$, low in available nitrogen $(253 \mathrm{~kg} / \mathrm{ha})$, medium in available phosphorus $(13.5 \mathrm{~kg} / \mathrm{ha})$ and very high in available potassium (201 $\mathrm{kg} / \mathrm{ha})$.

Four treatments $\mathrm{T}_{1}\left(75 \% \mathrm{RDF}\right.$ alone) $\mathrm{T}_{2}[75 \%$ $\mathrm{RDF}+5 \mathrm{t} /$ ha Vermi-compost + bio-fertilizers $($ Azolobacter + PSB) $], \mathrm{T}_{3}[75 \% \mathrm{RDF}+5 \mathrm{t} / \mathrm{ha}$ FYM + bio-fertilizer (Azolobacter + PSB)] and $\mathrm{T}_{4}(100 \%$ RDF alone) were applied. The experiment was laid out in randomized block design with three replications. The crop was transplanted manually on $31^{\text {st }}$ March, 2013. The plot size was $5 \times 4$ meters. The experiment was conducted by planting roots slips per hill at $60 \times 50 \mathrm{~cm}$ spacing and the crop was maintained as a perennial crop for two years. After sowing, the plots were immediately irrigated for proper moisture level and crop growth. Field was hand weeded at 25-30 days after sowing and after every cutting. Farm yard manure $5 \mathrm{t} / \mathrm{ha}$ and vermicompost 5t/ha enriched with bio-fertilizers (Azotobacter and PSB) were applied at the time of land preparation. Recommended dose of inorganic fertilizers consisting of $200 \mathrm{~kg} \mathrm{~N}$ and $60 \mathrm{~kg}$ each of $\mathrm{P}_{2} \mathrm{O}_{5}$ and $\mathrm{K}_{2} \mathrm{O}$ /ha in the form of Urea, SSP and MOP were applied to the crop. Full dose of phosphorous potassium and one fifth of nitrogen (i.e. $40 \mathrm{~kg} \mathrm{~N} / \mathrm{ha}$ ) was applied as a basal dose under control treatment. Remaining doses of nitrogen $40 \mathrm{~kg} / \mathrm{ha}$ under $100 \% \mathrm{RDF}$ and $30 \mathrm{~kg} / \mathrm{N} / \mathrm{ha}$ under $75 \%$ RDF according to treatment were top dressed at 30 days after transplanting and 
after every harvest except last. After completion of one year of experiment, again equal basal dose of FYM + bio-fertilizer, Vermi- compost + bio-fertilizers, Phosphorus and potash were mixed in soil between row spacing. During the experiment, four cuttings in each year were taken at $12-15 \mathrm{~cm}$ from ground level at regular interval of 90 days.

Weight of fresh fodder from each plot was recorded immediately after cutting and expressed in tones /ha. Dry matter was recorded by randomly selecting five plants from each plots and drying them @ 80+5 ${ }^{\circ} \mathrm{C}$ for 24 hours or until constant weight was achieved. Sample obtained from first cut in each year were analyzed for crude protein and crude fiber which was used for calculating the yield of crude protein and crude fiber of the fodder.

\section{Statistical analysis}

For analyzing the effect of treatments and cuts on fodder yield the following general linear model was applied.

$$
y_{i j}=\mu+G_{i}+C_{j}+(G C)_{i j}+e_{i j}
$$

\section{Where}

$y_{i j}=$ observed value of the response variable for $\mathrm{i}$-th group at $\mathrm{j}$-th day

$\mu=$ General mean effect

$C_{j}=$ Effect of $\mathrm{j}$-th cut

$(G C)_{i j}=$ Interaction of $\mathrm{i}$-th treatment and $\mathrm{j}$-th cut

The multiple comparisons between groups and cuts were done by using Tukey HSD test at $5 \%$ level of significance.

\section{Results and Discussion}

Hybrid Napier is a popular fodder grass among cultivated fodders, due to its high yielding potential and nutritive value. A field trial was conducted at ICAR-IVRI, Izatnagar, Uttar Pradesh, during the 2013-14 and 201415 on sandy loam soil, having $\mathrm{pH}$ around 7.0 and four treatments viz. T-1(75\% RDF alone) $\mathrm{T}-2[75 \% \mathrm{RDF}+5 \mathrm{t} / \mathrm{ha}$ Vermi-compost + bio-fertilizers (Azolobacter + PSB)], T-3 [75\% $\mathrm{RDF}+5 \mathrm{t} / \mathrm{ha} \mathrm{FYM}+$ bio-fertilizer (Azolobacter + PSB) and T-4 (100\% RDF alone] were tested. The results obtained from the experiment are presented below.

\section{Plant height}

The results of plant height during $1^{\text {st }}$ year and $2^{\text {nd }}$ year are presented in table 1 . Plant height was maximum $(152.12 \mathrm{~cm}, 13.05 \mathrm{t} / \mathrm{ha})$ with $75 \% \mathrm{RDF}+$ Vermi-compost + bio-fertilizers and significantly superior to those recorded in $100 \% \mathrm{RDF}$ as a control treatment. $(148.39 \mathrm{~cm}$, $11.86 \mathrm{t} / \mathrm{ha})$ followed by $75 \% \mathrm{RDF}+5 \mathrm{t} / \mathrm{ha}$ FYM + bio-fertilizer. The performance of Napier was better with the combined application of organic, inorganic and biofertilizers than that of the control.

\section{Fodder yield}

Fodder yield during $1^{\text {st }}$ and $2^{\text {nd }}$ year is presented in table 2 . The crop performance in respect to green fodder yield was significantly improved by combined application of organic, inorganic and bio-fertilizers than the inorganic alone. The pooled mean analyses of green fodder yield/cut showed that both the Integrated Nutrient Management (INM) treatments were at par with each other. Yield recorded in $\mathrm{T}_{1}$ (75\% RDF alone) was lowest (Table 2). The pooled analysis of fodder yield showed significantly higher yield (69.75 t/ha) with $\mathrm{T}_{2}(75 \% \mathrm{RDF}+$ Vermi-compost + biofertilizer) followed by $\mathrm{T}_{3}(75 \% \mathrm{RDF}+5 \mathrm{t} / \mathrm{ha}$ FYM + bio-fertilizer) $(67.73 \mathrm{t} / \mathrm{ha})$ and $\mathrm{T}_{4}(100$ 
\% RDF) (65.35 t/ha). The higher fodder yield in these treatments may be attributed to higher number of tillers in corresponding treatment. This increase in yield might be due to the additional amount of nutrients supplied by vermi-compost and FYM as well as the beneficial effects of organic matter addition which were derived in connection with the physical and chemical properties of the soil.

Application of organic manure in conjunction with lower doses of NP and K resulted in high growth and yield in fodder.

\section{Dry matter}

The dry matter yield of Napier during $1^{\text {st }}$ and $2^{\text {nd }}$ year is presented in Table 3 . The dry matter yield was significantly improved by combined application of organic, inorganic and bio-fertilizers than the inorganic alone.

The pooled mean analyses of dry matter yield/cut showed that both the Integrated Nutrient Management (INM) treatments were at par with each other. Yield recorded in $\mathrm{T}_{1}$ (75\% RDF alone) was lowest (Table 2). The pooled analysis of fodder yield showed significantly higher values (13.05 t/ha) with $\mathrm{T}_{2}$ (75\% RDF + Vermi-compost + bio-fertilizer) followed by $\mathrm{T}_{3}(75 \% \mathrm{RDF}+5 \mathrm{t} / \mathrm{ha} \mathrm{FYM}+$ bio- fertilizer (12.73 t/ha) followed by $\mathrm{T}_{4}(100 \%$ RDF treatment) (11.86 t/ha). The higher fodder yield in these treatments may be attributed to higher number of tillers in corresponding treatment. This increase in yield might be due to the additional amount of nutrients supplied by vermi-compost and FYM as well as the higher dry matter yield per cut accumulation may be attributed to the more plant height of the corresponding treatment. Similar to our results Anthony and Thomas (2015) found higher dry matter yield of DHN-6 variety may due to combination of better plant height and dry matter contents.

\section{Fodder production in different cuts}

During the experiment, four cuttings in each year were taken at regular interval of 90 days. First cut gave maximum yield of green fodder, D.M., CP, and CF (Table 1, 2, 3, 4 and 5) which were significantly lower in fourth cut. This may be due to winter low temperature during the last cut however, during first and second cut climate conditions were more suitable for growth and better fodder production. Similarly Khadda et al., (2013) also reported mean green fodder yields of 97 $\mathrm{t} / \mathrm{ha}$ in front line demonstrations of $\mathrm{BN}$ hybrid grass.

Table.1 Plant height $(\mathrm{cm})$ of Napier hybrid (Pooled data) under integrated nutrient management

\begin{tabular}{|c|c|c|c|c|c|}
\hline Treatment & Cut 1 & Cut 2 & Cut 3 & Cut 4 & $\begin{array}{r}\text { Treatment } \\
\text { Mean }\end{array}$ \\
\hline T1 & 141.04 & 146.28 & 129.41 & 66.74 & $120.86 \mathrm{c}$ \\
\hline T2 & 189.66 & 178.23 & 164.84 & 76.13 & $152.12 \mathrm{a}$ \\
\hline T3 & 183.62 & 172.83 & 174.53 & 73.07 & $151.02 \mathrm{ab}$ \\
\hline T4 & 181.28 & 175.68 & 162.04 & 74.54 & $148.39 \mathrm{~b}$ \\
\hline Mean (Cut) & $173.90 \mathrm{a}$ & $168.25 \mathrm{~b}$ & $157.62 \mathrm{c}$ & $72.62 \mathrm{~d}$ & \\
\hline
\end{tabular}

The treatments/cuts with common letters do not differ significantly at $5 \%$ level of significance. 
Table.2 Green fodder yield (t/ha) of Napier hybrid (Pooled data) under integrated nutrient management

\begin{tabular}{|c|c|c|c|c|c|}
\hline Treatment & Cut 1 & Cut 2 & Cut 3 & Cut 4 & Treatment Mean \\
\hline T1 & 78.87 & 76.09 & 54.68 & 26.11 & $58.48 \mathrm{c}$ \\
\hline T2 & 89.20 & 81.08 & 70.51 & 38.21 & $69.75 \mathrm{a}$ \\
\hline T3 & 84.27 & 81.20 & 68.11 & 37.35 & $67.73 \mathrm{ab}$ \\
\hline T4 & 92.40 & 69.85 & 61.18 & 37.98 & $65.35 \mathrm{~b}$ \\
\hline Mean(Cut) & $86.18 \mathrm{a}$ & $77.05 \mathrm{~b}$ & $63.62 \mathrm{c}$ & $34.91 \mathrm{~d}$ & \\
\hline
\end{tabular}

The treatments/cuts with common letters do not differ significantly at $5 \%$ level of significance.

Table.3 Dry matter yield (t/ha) of Napier hybrid (Pooled data) under integrated nutrient management

\begin{tabular}{|c|c|c|c|c|c|}
\hline Treatment & Cut 1 & Cut 2 & Cut 3 & Cut 4 & $\begin{array}{c}\text { Treatment } \\
\text { Mean }\end{array}$ \\
\hline T1 & 16.77 & 16.19 & 9.26 & 2.06 & $11.07 \mathrm{c}$ \\
\hline T2 & 18.86 & 17.94 & 12.09 & 3.30 & $13.05 \mathrm{a}$ \\
\hline T3 & 18.09 & 18.00 & 11.28 & 3.55 & $12.73 \mathrm{a}$ \\
\hline T4 & 18.36 & 14.92 & 10.13 & 4.10 & $11.86 \mathrm{~b}$ \\
\hline
\end{tabular}

The treatments/cuts with common letters do not differ significantly at $5 \%$ level of significance.

Table.4 Crude protein yield (t/ha) of Napier hybrid (Pooled data) under integrated nutrient management

\begin{tabular}{|c|c|c|c|c|c|}
\hline Treatment & Cut 1 & Cut 2 & Cut 3 & Cut 4 & $\begin{array}{c}\text { Treatment } \\
\text { Mean }\end{array}$ \\
\hline T1 & 1.47 & 1.42 & 0.81 & 0.18 & $0.97 \mathrm{c}$ \\
\hline T2 & 1.68 & 1.57 & 1.06 & 0.29 & $1.15 \mathrm{a}$ \\
\hline T3 & 1.66 & 1.58 & 0.99 & 0.31 & $1.13 \mathrm{a}$ \\
\hline T4 & 1.65 & 1.31 & 0.89 & 0.36 & $1.05 \mathrm{~b}$ \\
\hline $\begin{array}{c}\text { Mean } \\
\text { (Cut) }\end{array}$ & $1.62 \mathrm{a}$ & $1.47 \mathrm{~b}$ & $0.94 \mathrm{c}$ & $0.28 \mathrm{~d}$ & \\
\hline
\end{tabular}

The treatments/cuts with common letters do not differ significantly at 5\% level of significance.

Table.5 Crude fiber yield ( $\mathrm{t} / \mathrm{ha}$ ) of Napier hybrid (Pooled data) under integrated nutrient management

\begin{tabular}{|c|c|c|c|c|c|}
\hline Treatment & Cut 1 & Cut 2 & Cut 3 & Cut 4 & $\begin{array}{c}\text { Treatment } \\
\text { Mean }\end{array}$ \\
\hline T1 & 1.67 & 1.61 & 0.92 & 0.20 & $1.10 \mathrm{c}$ \\
\hline T2 & 1.88 & 1.79 & 1.20 & 0.32 & $1.30 \mathrm{a}$ \\
\hline T3 & 1.80 & 1.79 & 1.12 & 0.35 & $1.27 \mathrm{a}$ \\
\hline T4 & 1.83 & 1.48 & 1.01 & 0.40 & $1.18 \mathrm{~b}$ \\
\hline Mean (Cut) & $1.79 \mathrm{a}$ & $1.67 \mathrm{~b}$ & $1.06 \mathrm{c}$ & $0.32 \mathrm{~d}$ & \\
\hline
\end{tabular}

The treatments/cuts with common letters do not differ significantly at $5 \%$ level of significance. 


\section{Crude protein yield}

Nitrogen management significantly influenced the crude-protein yield of hybrid Napier fodder (Table 4). Significantly higher crude protein yield $(1.15 \mathrm{t} / \mathrm{ha})$ was found under application of $\mathrm{T}_{2}(75 \% \mathrm{RDF}+5 \mathrm{t} / \mathrm{ha}$ vermi-compost + bio-fertilizer) than with $100 \%$ RDF alone (1.05 t/ha).

Both treatments $\mathrm{T}_{2}(75 \% \mathrm{RDF}+5 \mathrm{t} / \mathrm{ha}$ vermicompost + bio-fertilizer) and $\mathrm{T}_{3}(75 \%, \mathrm{RDF}+$ 5t/ha FYM + Bio-fertilizers) were found at par by giving $1.15 \mathrm{t} / \mathrm{ha}$ and $1.13 \mathrm{t} / \mathrm{ha}$ which was higher compared as with $\mathrm{T}_{4}(100 \% \mathrm{RDF}$ (1.05t/ha). These results confirm the findings of Sadhu et al., (1990).

The treatments with Azotobacter + PSB application registered significantly higher total crude protein compared with no biofertilizer application (1.05t/ha, 0.97t/ha). This increase could be ascribed to increased dry matter yield. The results are in line with the findings of Kumar and Sharma (2002). Mean crude protein of Hybrid Napier varied from $6.46 \%$ to $8.7 \%$ as reported by Anthony and Thomas (2014).

\section{Crude fiber}

Total fibre yield is given in table 5. Integrated Nitrogen Management significantly influenced the crude-fibre yield of hybrid Napier fodder (Table 5). Significantly higher crude protein yield (1.30 t/ha) was found under application of $\mathrm{T}_{1}(75 \% \mathrm{RDF})$ and $\mathrm{T}_{2}$ (5t/ha vermi-compost + bio-fertilizer) than with $\mathrm{T}_{4}(100 \% \mathrm{RDF})$ alone (1.18 t/ha). INM significantly influenced the crude fiber content. Application of $\mathrm{T}_{3}(75 \% \mathrm{RDF}+5 \mathrm{t} / \mathrm{ha}$ $\mathrm{FYM}+\mathrm{BF}$ ) recorded minimum (24.7\%) content and it was at par with $\mathrm{T}_{2}(75 \% \mathrm{RDF}+$ $5 \mathrm{t} /$ ha vermi compost $+\mathrm{VC}+\mathrm{BF}(25.2 \%)$. The lowest $\mathrm{CF}$ content was observed under $\mathrm{T}_{2}$ $(75 \% \mathrm{RDF}+5 \mathrm{t} / \mathrm{ha} \mathrm{VC}+\mathrm{BF})$ and $\mathrm{T}_{3}(75 \%$
$\mathrm{RDF}+5 \mathrm{t} / \mathrm{ha} \mathrm{FYM}+\mathrm{BF})$ indicating improvement in fodder quality by these treatment.

The CF content was significantly influenced due to bio-fertilizer treatments. Maximum CF content $(26.6 \%)$ and $(25.5 \%)$ were recorded under no bio-fertilizers treatment and lowest CF $(24.7 \%, 25.2 \%)$ was recorded with azotobacter and PSB application treatment, indicating better quality of fodder. The reduction in $\mathrm{CF}$ content and the improvement in fodder quality under optimum organic and inorganic sources might be due to the increase in succulence. The increase content of $\mathrm{CF}$ in plant under $75 \%$ RDF and no bio-fertilizer application may reduce the palatability and digestibility.

The fertilizer applied to Napier showed significant influence on the performance of Napier. Application of $\mathrm{T}_{2}(75 \% \mathrm{RDF}+5 \mathrm{t} / \mathrm{ha}$ Vermi-compost + B.F.) and with 5t/ha FYM + B.F. recorded significantly higher values of plant height, dry matter and yield of green fodder. The minimum value was recorded with $75 \%$ green RDF alone indicating saving of the fertilizers up to the extent of $25 \%$. This might be owing to availability of nitrogen during entire growth season because of slow mineralization of organic nitrogen from vermi-compost and FYM applied to Napier hybrid fodder crop for round the year supply of green fodder. The present study clearly indicates that the application $\mathrm{T}_{2}(75 \% \mathrm{RDF}+$ $5 \mathrm{t} \mathrm{VC}+$ bio-fertilizer) or $\mathrm{T}_{3}$ (5t/ha FYM along with bio-fertilizer) improved the fodder quality and gave maximum forage production of multi cut forage Napier hybrid in sandy loam soils under irrigated conditions of western Uttar Pradesh.

\section{Acknowledgement}

The authors are highly thankful to the Incharge Livestock Production and 
Management Section for valuable suggestions. The authors are also highly thankful to the Director, ICAR-Indian Veterinary Research Institute, Izatnagar, Bareilly, Uttar Pradesh for providing the facilities to carry out the research work.

\section{References}

Anthony S and Thomas C G (2014). Nutritive quality of hybrid Napier cultivars grow under rainfed ecosystem. Journal of Tropical Agriculture 52(1): 90-93.

Anthony S and Thomas C G (2015). Shade tolerance of selected hybrid Napier cultivars under rainfed conditions. Journal of Tropical Agriculture 53(1): 35-41.

Khada, B S, J K Kanak Lata, Jadav, R Kumar and A K, Rai (2013). Evaluation of BN hybrid in Panchmahal district of Central Gujrat, Indian Journal of Agricultural Sciences 83(9): 977-980.
Kumar and Sharma B L (2002). Effect of FYM, nitrogen and Azospirilium, inoculation on yield of fodder sorghum. Forage. Research 28(3): 165-168.

Sadhu A C, Patel J R, Patel P C and Patel, B.G. (1990). Cutting and nitrogen management studies in different genotypes of oats. Forage Research 16(2): 107-112.

Sharma A, Singh H and Manwal R K (2007). Effect of integrated nutrient management on productivity of wheat under limited and adequate irrigation supplies. Indian Journal of Agronomy 52(2): 120-123.

Shukla L and Tyagi, S P (2009). Effect of integrated application of organic manures on soil parameters and growth of mungbean (Vigna radiata). Indian Journal of Agricultural Sciences 79(3): 197-199.

\section{How to cite this article:}

Om Singh, V.B. Chaturvedi, M.R. Verma and Singh, H.C. 2018. Effect of Integrated Nutrient Management on Hybrid Napier Production under Irrigated Conditions. Int.J.Curr.Microbiol.App.Sci. 7(04): 2731-2737. doi: https://doi.org/10.20546/ijcmas.2018.704.311 